\title{
Synthesis of PbS Thin Film by Dip Coating Technique for Sensitization of Large band gap Semiconductor J K Dongre
}

Department of Physics, Government Autonomous Post Graduate College Chhindwara, Madhya Pradesh, India

\section{Article Info}

Volume 8, Issue 2

Page Number : $312-315$

\section{Publication Issue}

March-April-2021

\section{Article History}

Accepted : 10 March 2021

Published : 20 March 2021

\section{ABSTRACT}

Thin film of Lead sulfide $(\mathrm{PbS})$ is synthesized via low cost dip coating technique using precursors $\mathrm{Pb}\left(\mathrm{NO}_{3}\right)_{2}$ and thiourea for lead ions $\mathrm{Pb}^{+2}$ and sulfide ions $\mathrm{S}^{-2}$ respectively. The film is synthesized in alkaline medium. The as grown films onto glass slides were characterized by atomic force microscopy and UVvis spectroscopy. The AFM image shows agglomeration of particles. The band gap value estimated from the UV-vis spectra as $1.49 \mathrm{eV}$. The photoelectrochemical (PEC) performance of cell was estimated in two electrode configuration. The thin film of PbS in PEC cell exhibited efficiency of $0.09 \%$ with fill-factor of $41 \%$ in polysulfide solution.

Keywords : $\mathrm{PbS}$, dip coating technique, atomic force microscopy, UV-vis spectroscopy, photoelectrochemical cell

\section{INTRODUCTION}

Several oxide materials including $\mathrm{TiO}_{2}, \mathrm{ZnO}$ etc have been employed in dye sensitize solar cell. All these materials have band gap on the order of $3.0 \mathrm{eV}$. Calculations show that a band gap in the range of $1 \mathrm{eV}$ to $1.5 \mathrm{eV}$ is highly desirable in optimized solar cells. Wide band gap materials can absorb only few percent of solar spectrum in UV region result in low efficiency. Sensitization of large band gap semiconductor by small band gap materials is key solution for solar cell application. The small band gap materials viz CdS [A, B, C], CdSe [D], CdTe [E], HgS $[\mathrm{F}]$ and $\mathrm{PbS}[\mathrm{G}]$. Among the materials Lead sulphide $(\mathrm{PbS})$ is an excellent semiconductor which exhibits a band gap of $\sim 1-1.4 \mathrm{eV}$ by controlling the size of crystals.

For synthesize of $\mathrm{PbS}$ nanocrystals, different methods have been employed. $\mathrm{PbS}$ thin films can be prepared via different methods such as chemical bath deposition (CBD) [1,2], successive ionic layer adsorption reaction (SILAR) [3], electro-deposition, and vacuum evaporation [4]. Among the methods dip coating is a very comfortable and most convenient method for deposition nanocrystalline lead sulfide $(\mathrm{PbS})$ thin films. The dip coating technique is relatively inexpensive and simple since it does not require sophisticated equipment. 


\section{METHODS AND MATERIAL}

All the chemicals were used without further purification. The chemicals were used as lead nitrate $\mathrm{Pb}\left(\mathrm{NO}_{3}\right)_{2}$, thiourea and sodium hydroxide $[\mathrm{NaOH}]$. The lead nitrate was used for lead ions $\mathrm{Pb}^{+2}$, thiourea for sulfide ions $\mathrm{S}^{-2}$. Besides, sodium hydroxide was used for alkaline medium which also act as complexing agent to vary the $\mathrm{pH}$ of the reaction bath and to control the $\mathrm{Pb}^{+2}$ ions concentration. Substrate cleaning plays an important role in the deposition of thin films. Extreme cleanness of the substrate is required for the deposition as the contaminated substrate surface provides nucleation sites facilitating growth resulting non- uniform films. The commercial glass slides and Titanium ( $\mathrm{Ti}$ ) were used as substrates. The following procedure was adopted for cleaning of substrate.

1. The substrates were washed with double distilled (DD) water,

2. Then etched in dilute hydrochloric acid for a few second,

3. Again, the substrates were washed with detergent, rinsed in DD water,

4. Finally, the substrates were dried, degreased in AR grade acetone and were used for deposition.

5. To prepare $\mathrm{PbS}$ thin films the concentration of reagents were used as $0.1 \mathrm{M}$ of $\mathrm{Pb}\left(\mathrm{NO}_{3}\right)_{2}$ and and $0.6 \mathrm{M}$ of $\mathrm{SC}\left(\mathrm{NH}_{2}\right)_{2}$. In a typical procedure, firstly in the solution of lead nitrate, the sodium hydroxide solution was added slowly. This solution was stirred for several minutes the solution becomes colorless. To this solution the solution of thiourea was added slowly and stirred till the color of the solution becomes dark gray which indicates the $\mathrm{PbS}$ compound formation. Then synthesis of $\mathrm{PbS}$ films were carried out by dipping the glass slides vertically in the prepared solution by withdrawal speed of $1 \mathrm{~cm}$ in 30 second. The as grown films were removed from the bath and rinsed with distilled water. The resulting films were homogeneous, well adhered to the substrate with mirror-like gray aspect.

E. Pentia et al [5] have proposed the formation of thin film of by the reaction mechanism as follows:

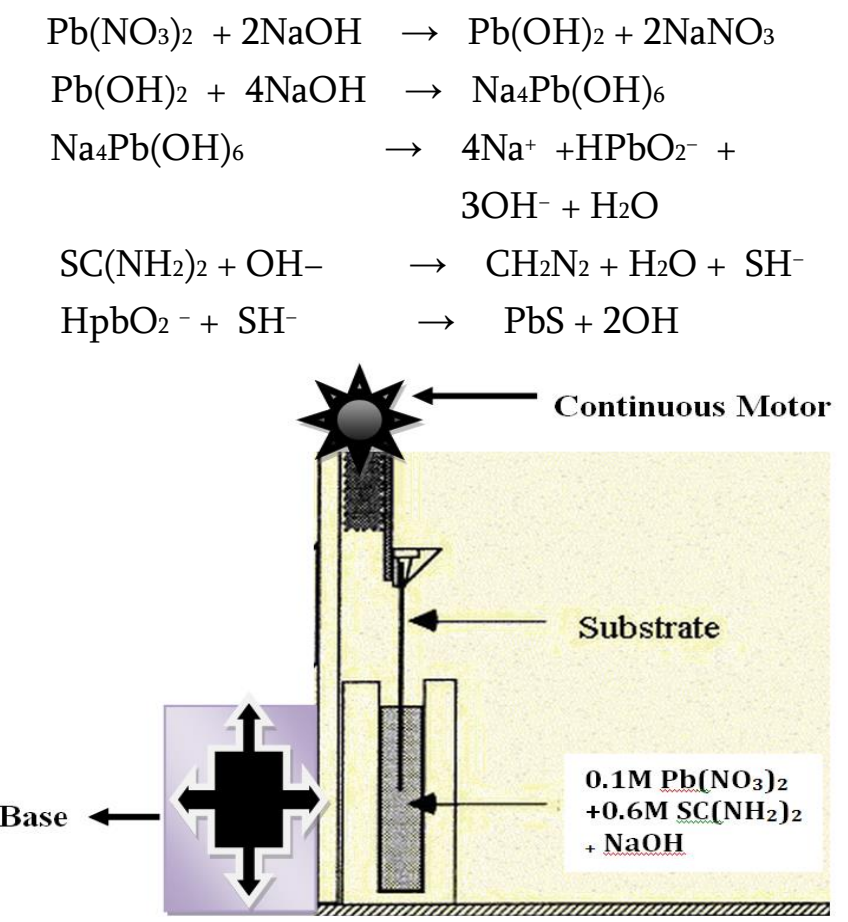

Figure 1 : Experimental layout diagram of DipCoating apparatus.

The surface morphology of the film was characterized by atomic force microscopy (AFM; DIAFM-4). The transmission data in the range $800-1100 \mathrm{~nm}$ were obtained with shimadzu uv-1800 spectrophotometer. The PEC cell was constructed using as grown films of $\mathrm{PbS}$ onto $\mathrm{Ti}$ as photoelectrode, and polysulfide as an electrolyte with graphite as the counter electrode. The polysulfide solution was used as an electrolyte in methanol/water (7:3 by volume). The polysulfide solution by means of it contains 1 Molar of each reagent of $\mathrm{Na} 2 \mathrm{~S}, \mathrm{~S}$ and $\mathrm{NaOH}$. [H]. Photocurrentvoltage (I-V) performances of as-deposited $\mathrm{PbS}$ photoelectrodes were measured under $100 \mathrm{~mW} / \mathrm{cm}^{2}$ light illumination intensity. The intensity of light was measured by Solar Power Meter (Tenmarsh Brand Model TM-207). The thickness of PbS film was measured by weight different gravimetric methods 
employing sensitive electronic microbalance. Thickness of film was estimated around $800 \mathrm{~nm}$.

\section{RESULTS AND DISCUSSION}

\section{A. Morphology of $\mathrm{PbS}$ film}

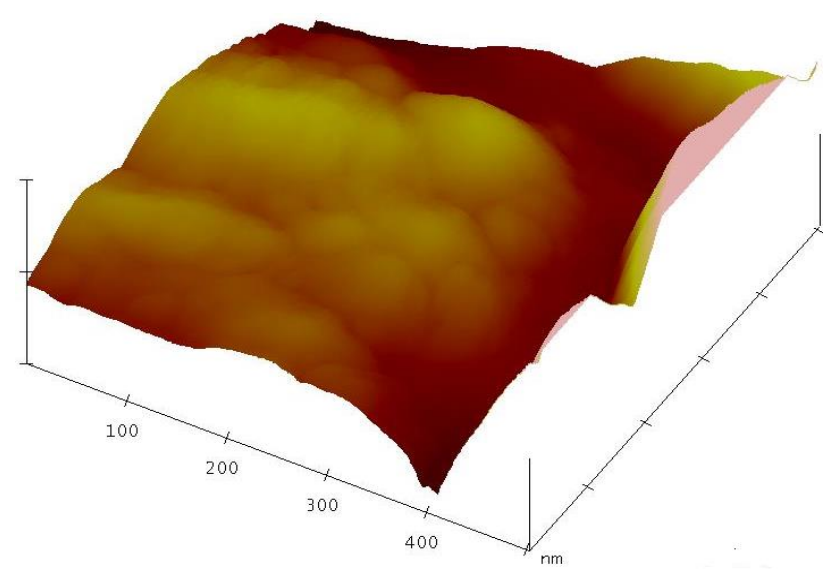

Figure 2: AFM image of $\mathrm{PbS}$ thin film

The surface morphology of films is studied by taking the AFM image. Figure 2 shows AFM 3-D image of $\mathrm{PbS}$ film. It is observed that the film covers the substrate very well. The morphology depicts that the grown film have large grains. The small particles group together and form as such large grain. It is clearly seen that the films are not uniform over the scan area of substrates.

\section{B. OPTICAL STUDY}

The absorption spectra of $\mathrm{PbS}$ thin film shown in Fig.

3. The absorption edge of the film can be seen around at $830 \mathrm{~nm}$ from which the band gap value has been estimated. The band gap value can be estimated as $1.49 \mathrm{eV}$.

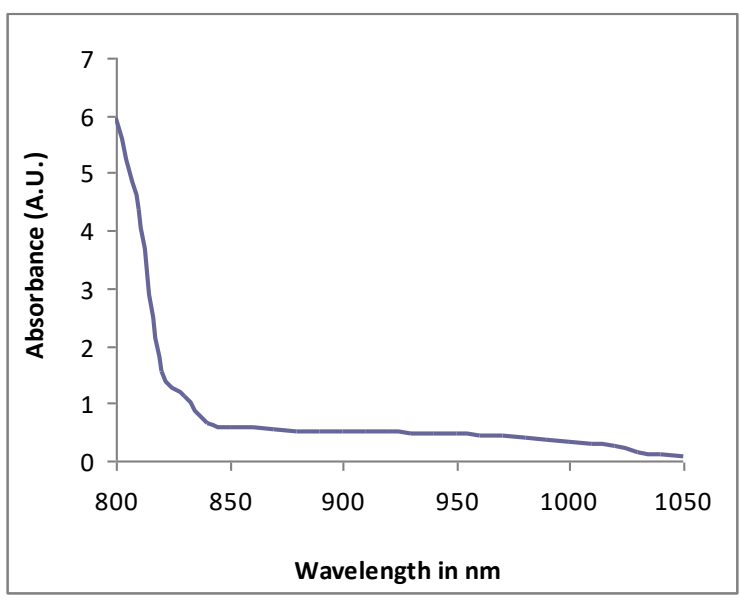

Figure 3: Absorption spectra of PbS film.

The photovoltaic power output characteristics of the $\mathrm{PbS}$ photoelectrode is obtained in two electrode configuration as depicted in the Fig. 4. For the $\mathrm{PbS}$ based PEC cell in polysulfide solution, a short-circuit photocurrent (Isc) of $706 \mu \mathrm{A}$, open circuit photovoltage ( $V o c$ ) of $250 \mathrm{mV}$, and a fill factor (ff) of $41 \%$ are obtained. For the obtained data the power conversion efficiency ( $\eta$ ) of $0.09 \%$, is calculated.

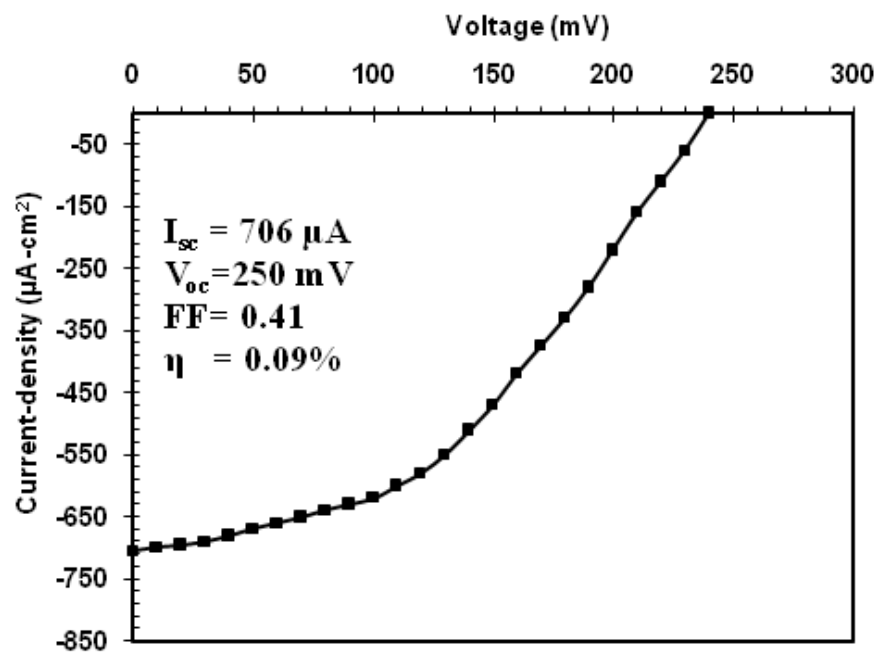

Figure 4: Photovoltaic power output characteristics of the $\mathrm{PbS}$ photoelectrode

\section{CONCLUSION}

This study presented deposition of $\mathrm{PbS}$ thin films by dip coating technique. UV-vis spectrophotometric studies showed that the direct band gap of $\mathrm{PbS}$ thin was estimated as $1.49 \mathrm{eV}$ from the absorption edge. 
The films have suitable band gaps to be used for solar cell applications. $\mathrm{PbS}$ thin film is a appropriate material for solar cells and can be used as an absorbing material in thin film solar cells due to its good optical properties.

\section{REFERENCES}

[1]. J. K. Dongre Int J Appl Res 3(3) (2017) 504-507. E-ISSN Number: 2394-5869

[2]. J.K. Dongre, V. Nogriya, M. Ramrakhiani, Applied surface science 255 (2009) 6115-6120, doi: https://doi.org/10.1016/j.apsusc.2009.01.064 ISSN: 0169-4332

[3]. J.K. Dongre, M. Ramrakhiani, Journal of Alloys and Compounds 487(2009) 653-658 doi:https://doi.org/10.1016/j.jallcom.2009.08.03 1

[4]. Na-Ri Kim, Sae-WanKim, Jin-Hyuk Bae, ShinWon Kang, Thin Solid Films 709 (2020) 138120,doi:

https://doi.org/10.1016/j.tsf.2020.138120

[5]. Yinyan Gong Yujie Wu, Yan Xu, Lei Li, Can Li, Xinjuan Liu, Lengyuan Niu Chemical Engineering Journal, 350 (2018) 257-267, doi: https://doi.org/10.1016/j.cej.2018.05.186

[6]. H Safardoust-Hojaghan, M Shakouri-Arani, M Salavati-Niasari. Transactions of Nonferrous Metals Society of China 26 (3) (2016) 759-766, doi: $\quad$ https://doi.org/10.1016/S10036326(16)64166-3

[7]. Sandeep Kumar; Rohitash Upadhyay; Basudev Pradhan, Solar Energy, 211 (2020) 283-290, https://doi.org/10.1016/j.solener.2020.09.063

[8]. J.K. Dongre, Mahim Chaturvedi, Yuvraj Patil, Sandhya Sharma and U.K. Jain :AIP Conference Proceedings 1670 (2015) 030007 doi: 10.1063/1.4926691

[9]. G. Hodeso Chem. Phys. 9 (2007) 2181.

[10]. S.M. Pawar, B.S. Pawar, J.H. Kim, O.S. Joo, C.D. Lokhande, Curr. Appl. Phys. 11 (2011) 117-161 doi:10.1016/j.cap.2010.07.007
[11]. K.C. Preetha, K.V. Murali, A.J. Ragina, K. Deepa, T.L. Remadevi, Curr. Appl. Phys. 12(2012) 53.

[12]. S. Kumar, T.P. Sharma, M. Zulfequar, M. Husain, Physica B, 325 (2003) 9.

[13]. E. Pentia, I. Pintilie, T. Botila, I. Pentilie, A. Chaparro, C. Maffiotle, Thin Solid Films 434 (2003) 162-170, DOI: https://doi.org/10.1016/S0040-6090(03)00449-8, ISSN 0040-6090

\section{Cite this article as :}

J K Dongre, "Synthesis of PbS Thin Film by Dip Coating Technique for Sensitization of Large band gap Semiconductor", International Journal of Scientific Research in Science and Technology (IJSRST), Online ISSN : 2395-602X, Print ISSN : 2395-6011, Volume 8 Issue 2, pp. 312-315, March-April 2021. Available at doi $\quad$ : https://doi.org/10.32628/IJSRST218248 Journal URL : https://ijsrst.com/IJSRST218248 